\title{
Effectiveness of an antihelminthic treatment in improving the body condition and survival of Hawaiian monk seals
}

\author{
K. S. Gobush ${ }^{1, *}$, J. D. Baker ${ }^{1}$, F. M. D. Gulland ${ }^{2}$ \\ ${ }^{1}$ Pacific Island Fisheries Science Center, National Marine Fisheries Service, \\ National Oceanic and Atmospheric Administration, Honolulu, Hawaii 96814, USA \\ ${ }^{2}$ The Marine Mammal Center, Sausalito, California 94965-2609, USA
}

\begin{abstract}
Food limitation and poor body condition are significant factors affecting the survival of juvenile Hawaiian monk seals Monachus schauinslandi in the Northwestern Hawaiian Islands. Previous research has indicated that juvenile monk seals infected with cestodes are in worse body condition than those that are uninfected. To test whether individual growth and survivorship are boosted by intermittently reducing parasites, we initiated a deworming study on juvenile seals at Laysan Island. Forty-three unique juvenile seals were captured, weighed, measured, feces-sampled, and either given an injectable antihelminthic (praziquantel) or used as untreated controls up to 4 times at 8 to $16 \mathrm{wk}$ intervals across a 7 month period. The effect of treatment on survival, egg shedding, and gain in mass was evaluated. Survival of the subset of the 3 cohorts included in the study was $100 \%$ for the 2007 and 2008 cohorts and $85.2 \%$ for the 2009 cohorts. Egg prevalence did not differ significantly between control and treated seals. Percent daily mass gain was greatest in the March to May period. Older juveniles gained more mass than young-of-the-year (treated and control), which lost mass between the first 2 treatments. Percent mass gain was significantly greater for treated than control seals during March to May, but not during December to March or over the entire treatment period (December to May). The questionable efficacy of injectable praziquantel indicates that a different route of administration or dosage of praziquantel or a different antihelminthic may be more suitable for treatment of cestodes in this species.
\end{abstract}

KEY WORDS: Hawaiian monk seal · Monachus schauinslandi $\cdot$ Antihelminthic $\cdot$ Praziquantel · Cestodes

Resale or republication not permitted without written consent of the publisher

\section{INTRODUCTION}

Abundance of the Critically Endangered Hawaiian monk seal is declining as a result of low juvenile survival, which appears to be associated with food limitation and poor body condition (Baker 2008). Monk seals have a variety of endoparasites (Dailey et al. 1988), some of which are associated with poor body condition: infection with Diphyllobothrium spp. (cestodes) is associated with decreased axillary girth in juvenile monk seals in the Northwestern Hawaiian
Islands (NWHI; Reif et al. 2006). Numerous studies of domestic animals have demonstrated that reduction of parasites can improve body condition or increase survival (e.g. Forbes 1993, Faizal et al. 2002). Although studies of wild mammals have associated parasite burden with condition or survival (Lello et al. 2005), few intervention studies with antihelminthics have been carried out. Reducing nematode burden (Trichostrongylus species) with albendazole enhanced the survival of wild juvenile Soay sheep Ovis aries (Gulland et al. 1993, Craig et al. 2009). 
Experimental control of the nematode $T$. tenuis with levamisole hydrochloride consistently increased the breeding production and winter survival of red grouse Lagopus lagopus scoticus (Hudson et al. 1992). Northern fur seal Callorhinus ursinus pups treated with ivermectin to reduce hookworm Uncinaria lucasi infection experienced increased growth and decreased mortality compared to control animals (DeLong et al. 2009).

The cestodicide praziquantel is widely used to control parasites in domestic animals and livestock, and the drug is commonly used for the treatment of rehabilitated pinnipeds (Andrews \& Thomas 1983, Dierauf \& Gulland 2001). Anecdotally, some captive monk seals have passed tapeworms within days of praziquantel treatment (National Marine Fisheries Service [NMFS] unpubl. data). Here, we evaluated for the first time the effects of antihelminthic treatment on Hawaiian monk seals and the utility of this intervention to improve survival. We tested the hypotheses that (1) a common deworming medication, injectable praziquantel, is safe and effective in reducing worm burdens in juvenile monk seals, and (2) intermittently reducing worm burdens in juvenile monk seals is associated with improved body condition and increased probability of survivorship.

\section{MATERIALS AND METHODS}

\section{Study site}

We studied Hawaiian monk seals at Laysan Island aged young-of-the-year to 2 yr old, born during 2007 to 2009. Laysan Island is a single, uninhabited land mass (area: $\left.4.11 \mathrm{~km}^{2}\right)$ in the NWHI $\left(25^{\circ} 42^{\prime} 14^{\prime \prime} \mathrm{N}\right.$, $171^{\circ} 44^{\prime} 04^{\prime \prime} \mathrm{W}$ ) and is one of 6 main Hawaiian monk seal breeding sites in the archipelago. Laysan Island was selected because a relatively large number of pups are born there annually and the island manifests a minimum of mortality factors (e.g. predation), other than food limitation, to confound the results.

Seals had been uniquely marked, typically within days of weaning, with 2 rear-flipper tags and an implanted passive integrated transponder (PIT) tag. Hawaiian monk seals exhibit a protracted pupping season, with most births occurring from March to May (Johanos et al. 1994). The present study was conducted from November 2009 to November 2010. For convenience, we considered seals to be 1 yr older beginning on 1 January of a given year. Accordingly, at the conclusion of this study, seals were 1 (2009 cohort), 2 (2008 cohort), and 3 (2007 cohort) yr old.

\section{Treatment administration}

To test whether antihelminthic treatment improves body condition and survival, we focused on seals that could potentially benefit from treatment, but were not already so compromised as to be unlikely to survive under any circumstances. Thus, we excluded animals visually scored as emaciated (see below). Also, seals were not captured during their catastrophic molt as a precaution against causing undue stress during handling. We captured seals on land by hand and hoop net, weighed and measured them (axillary girth and dorsal straight length), and attempted to collect feces from the rectum using a fecal loop or a gloved finger. Each seal was randomly assigned either to be treated with an injectable antihelminthic (praziquantel, injectable Droncit ${ }^{\circledR}$, Bayer; dose $5 \mathrm{mg} \mathrm{kg}^{-1}$ ) or to serve as a control. During each treatment period, treated seals received the full dose of praziquantel in 1 or 2 injections. Controls were not sham-injected or injected with a placebo because minimizing the associated risks to the seals and the field team outweighed this minor improvement to the experimental design. As a result, handling of the 2 groups was similar in all respects except the injection site cleaning and injection of the antihelminthic. The handling time of treated seals averaged $84 \mathrm{~s}$ longer than that of controls (controls: $7.7 \pm 1.5 \mathrm{~min} \mathrm{SE}$; treated seals: $9.1 \pm 1.9 \mathrm{~min}$ ). Any negative effects associated with the longer handling time of treated seals likely rendered the study more conservative in that this would make detecting a positive effect of treatment more difficult. With a single field team conducting the study, it was not possible to keep the researchers blind to each seal's treatment assignment. However, this likely did not bias our metrics because survival and mass were objective measures, and the examination of fecal egg presence was conducted blind (i.e. a third party analyzed the fecal samples in the laboratory without knowing the seals' treatment group).

In a pretrial of this study, we discovered that oral antihelminthics were challenging to administer. We treated 7 monk seals (aged 1 and 2 yr old) with oral praziquantel powder (Droncit ${ }^{\circledR}$, Bayer, dose $5 \mathrm{mg}$ $\mathrm{kg}^{-1}$ ) mixed in an oral nematodicide, fenbendazole paste (Panacur 10\% ${ }^{\circledR}$, Intervet/Schering-Plough Animal Health, dose $10 \mathrm{mg} \mathrm{kg}^{-1}$ ); 5 additional seals served as controls. Some seals received as little as $30 \%$ of their intended dose because they clenched their jaws, spat out the medication or flushed their mouths upon entering the water, thus tending to increase handling time. However, a 1-way analysis of 
variance (ANOVA) showed that the difference in percent daily gain in mass was nearly significantly greater in treated seals than in controls (ANOVA, $\mathrm{R}^{2}$ $\left.=0.32, F_{11,1}=4.71, p=0.055\right)$. These results suggested that treatment with antihelminthics warranted more investigation but that a more reliable route of administration was needed. We therefore used injectable praziquantel during the continuation of the study (fenbendazole was not available in an injectable form, so we did not include a nematodicide in this study).

We weighed seals in a custom-made stretcher net suspended from a scale (Johnson Scale Company, model MSI 7200 dynalink digital dynoamometer, $500 \mathrm{~kg}$ capacity) attached to a custom-made carbonfiber tubing tripod. We preserved fecal samples (volume up to $3 \mathrm{~g}$ ) for subsequent helminth egg counts in a plastic-capped vial with a premeasured volume of SAF fixative (an aqueous solution of $10 \%$ formaldehyde, acetic acid and sodium acetate). In addition to weighing the seals, body condition was qualitatively scored based on visual inspection during regular resightings, supplemented by examination of digital photos. We used a suite of qualitative indices that rely on the relative visibility of boney protrusions to reflect body condition (i.e. ischium, greater trochanter of the femur, ilium, ribs, scapulohumoral joint, dorsal spinous processes and transverse processes of vertebrae, and circumferential loss of mass around the neck and cranial shoulders). Young-of-the-year entered the study when they were at least $120 \mathrm{~d}$ of age, when the parasite burden is likely to be detectable, according to helminth egg counts performed on 54 monk seals from 1 to $150 \mathrm{~d}$ old (NMFS unpubl. data).

We attempted to closely monitor treated seals for $10 \mathrm{~d}$, and control seals for $3 \mathrm{~d}$, following capture for adverse reactions (e.g. vomiting, diarrhea, jaundice, lethargy, general signs of discomfort). Seals were resighted during almost daily surveys of the island's shoreline, and each time their body condition was visually assessed.

We repeated this basic capture, treatment, and monitoring procedure 4 times at approximately 8 to 16 wk intervals. Treatment periods were 29 November 2009 through 8 January 2010; 14 February through 6 March 2010; 21 May through 24 June 2010; and 9 August through 5 September 2010; however, only a subset of the study's seals were included in the last treatment (see 'Efficacy test' below). We also captured and weighed some seals in the period 19 October to 7 November 2010 to obtain post-treatment measurements only. For brevity, the periods are here- after referred to as the month in which the greatest number of seals was handled within each period: December, March, May, August, and October, respectively. The number of days between captures of individual seals ranged from 54 to 110 . The treatment interval balanced seal haul-out patterns and the number of total handlings per seal with the goal of intermittently reducing parasite burden across a large portion of the year when survivorship is often compromised. The time between treatments sufficiently exceeded the prepatent period for Diphyllobothrium spp. (i.e. the period between infection of the host and the earliest time at which eggs can be recovered from feces). The treatment interval was also manageable logistically because individual seals were sighted during patrols conducted on an almost daily basis, and were available for opportunistic capture.

\section{Efficacy test}

In August, we also conducted a field efficacy test of injectable praziquantel on a subset of $1 \mathrm{yr}$ old seals to determine whether the deworming medication was effective in killing adult tape worms in this species. The basic capture, weighing, and treatment scheme was repeated on $221 \mathrm{yr}$ old seals; additionally, an attempt to collect a second fecal sample from each individual was made up to $22 \mathrm{~d}$ after capture (the expected prepatent period for cestodes). Each seal maintained its previous treatment group assignment; there were 11 control and 11 treated 1 yr olds. We attempted to recover a post-treated sample from each seal by searching the beach for fresh scat. Fresh scat was identified as coming from an individual seal if it was very near the seal's body or within the imprint or tracks that led to an identifiable resting seal on the beach. If a beach scat was not recovered for a treated seal by $15 \mathrm{~d}$ post capture, we attempted to recapture the individual to collect a fecal sample before $22 \mathrm{~d}$ post treatment had passed. To minimize handling, we did not recapture the control seals.

\section{Analysis}

The effect of treatment on survivorship, presence of cestode eggs in sampled feces, and mass change were evaluated. We determined the subsequent survival of a seal through visual re-identification until October 2010. If a seal in our study was not seen at least once this month, it was counted as not surviving. 
We used the McMaster egg-counting techniqueMinistry of Agriculture, Fisheries and Food (MAFF) (1986) Manual of veterinary parasitological laboratory techniques. Reference Book 418. 3rd edn, HMSO, London - to examine blind for the presence of cestode (family Diphyllobothriidae) egg and nematode (family Anisakidae) eggs on fecal samples collected from seals during capture. We did not examine samples smaller than $1 \mathrm{~g}$. Egg presence rather than intensity was recorded in particular for Diphyllobothrium species because egg release by tapeworms is intermittent via proglottid desegmentation (Cheng 1986). Although seals did not receive a nematodicide in this trial, we examined nematode egg prevalence to track the frequency of this type of parasitic infection in monk seals.

Mass change was expressed as a percent of initial mass, because a seal's size at the beginning of an interval may influence its potential to accumulate mass. We calculated absolute growth rate for seals between each set of treatment intervals by dividing the change in mass in kilograms by the number of days between captures. Percent growth rate was calculated as absolute growth rate divided by mass during the capture that occurred at the beginning of the interval, multiplied by 100 . The effect of treatment on percent growth rate, as a repeated measures variable across the 2 intervals (the time between the December and March treatments and the March and May treatments, respectively), was examined via a repeated measures general linear model (RM GLM) in SAS JMP version 8 and SPSS version 18 (IBM) (Grafen \& Hails 2004). Sex, age, and length of interval (in days) were included as covariates. Two-way interactions of factors and covariates were also examined. We removed nonsignificant $(p>0.05)$ factors and interactions from the initial model by a backwards-stepwise elimination to generate a minimum acceptable model. We performed univariate analyses on any factors found to be significant across the repeated measures variable to further examine the time period when treatment might be most beneficial. Statistical tests on growth rate were 2-tailed with $\alpha=$ 0.05. Statistical power analysis, based on standard deviations observed for mass change in the December to March interval and the March to May interval, indicated that our RM GLM sample size (18 per group) should give a $>80 \%$ probability of correctly detecting a real difference of 1 SD between groups.

\section{RESULTS}

Forty-three Hawaiian monk seals met the criteria for inclusion in this study. We treated approximately half of the study population with de-worming medication at approximately 8 to 16 wk intervals from the December (2009) period until the May (2010) period (Table 1). In August, the efficacy test was conducted on yearlings only. We chose to forego treatment of 2 and 3 yr old juveniles after May because of their high survival rate and their increased size (some seals exceed $100 \mathrm{~kg}$ ), and to minimize handling and harmful risks to individual seals. From October to November 2010, only follow-up weights were obtained from yearlings. In total, 161 captures and 78 injections were made. Sample size decreased across treatments because of the disappearances of seals (likely deceased; for descriptions see 'Survival'), the removal of a seal from the study as a result of an abscess (description below), and the removal of a seal from the study because of its excessive size (greater than $100 \mathrm{~kg}$ ) and behavior (extremely active during capture).

\section{Efficacy of injectable praziquantel}

We collected at least 1 scat sample from 19 of 22 juvenile seals (1 yr old) during or after capture. For treated seals, the presence or absence of cestode eggs in post-treatment scats was used to evaluate the efficacy of praziquantel in reducing fecal egg presence. Cestode eggs were present in all scats collected at the time of capture $(9$ control and 8 treated seals) and in all scats collected 10 to $22 \mathrm{~d}$ after capture or treatment ( 1 control and 7 treated seals).

\section{Survival}

The survival rate of the seals that entered this study was high. When we initiated the study, some mem-

Table 1. Monachus schauinslandi. Antihelminthic treatments and measurements carried out at Laysan Island, Northwestern Hawaiian Islands

\begin{tabular}{|llc|}
\hline Dates & Procedure & $\begin{array}{c}\text { No. seals } \\
\text { (no. treated) }\end{array}$ \\
\hline 29 Nov 2009 - 8 Jan 2010 & Treatment, all juveniles & $43(23)$ \\
14 Feb - 6 Mar 2010 & Treatment, all juveniles & $40(20)$ \\
21 May - 24 Jun 2010 & Treatment, all juveniles & $37(19)$ \\
9 Aug - 5 Sep 2010 & Efficacy test, 1 yr olds & $22(11)$ \\
19 Oct - 7 Nov 2010 & Mass measurement only, 1 yr olds & 19 \\
\hline
\end{tabular}


bers of the 2007, 2008, and 2009 cohorts were already missing and presumed dead, so the overall cohort survival was lower than that of the subset of animals involved in the antihelminthic trial. For the subset of the 2007 and 2008 cohorts that entered this study, $100 \%$ were observed alive as of October. For the subset of the 2009 cohort that entered this study, $85 \%$ (23 of 27) were observed alive as of October (2010) (Table 2).

The only measured difference in survival of treated and control seals, that of 2009 cohort seals from weaning to Age $1 \mathrm{yr}$, was not statistically significant (Fisher's exact test, $\mathrm{n}=27, \mathrm{df}=1, \mathrm{p}=0.61$ ). Details surrounding the disappearances of the four 2009 cohort seals are as follows. One seal suffered minor dorsal bites and scratches consistent with conspecific male aggression prior to her disappearance in April 2010 but otherwise appeared healthy. A second seal presented with a dorsal anterior wound of low severity from an unknown source and disappeared in late January 2010. A third seal suffered a severe shark injury prior to the commencement of the study, had a wounded flipper attributed to unknown cause in December 2009, and disappeared in late January 2010. The fourth missing seal experienced respiratory distress on several occasions and disappeared in late February 2010.

\section{Fecal egg presence}

An attempt to collect fecal samples was made during every capture; however, only $58 \%$ of captures resulted in a sample with sufficient volume for examination (27 samples in December, 23 in March, and 20 in May). We detected cestode eggs in $97 \%$ of the samples overall: 43 of 44 samples from controls and 44 of 46 samples from treated seals. Significant differences in the percent of samples positive for cestodes per capture session between control and treated seals were not apparent (ANOVA, $\mathrm{n}=6, \mathrm{df}=4, \mathrm{p}=0.58$ ). The interval between treatment periods exceeds the prepatent period of Diphyllobothrium species; there-

Table 2. Monachus schauinslandi. Survival rate of Hawaiian monk seals in 2007, 2008, and 2009 cohorts. Values are resight ratios, with percent in parentheses

\begin{tabular}{|ccccc|}
\hline Cohort & Age class & Entire cohort & Control seals & Treated seals \\
\hline 2007 & 2 to $3 \mathrm{yr}$ & $9 / 10(90)$ & $4 / 4(100)$ & $5 / 5(100)$ \\
2008 & 1 to 2 yr & $7 / 14(50)$ & $3 / 3(100)$ & $4 / 4(100)$ \\
2009 & Young-of-the-year & $27 / 31(87)$ & $12 / 13(92)$ & $11 / 14(78.6)$ \\
\hline
\end{tabular}

fore, treatment with praziquantel was not expected to preclude reinfection by the subsequent sampling.

The presence of nematode eggs appeared to be more variable than that of cestode eggs. The number of nematode eggs $\mathrm{g}^{-1}$ ranged from 100 to 2000; eggs were present in $22 \%$ of the December samples, $27 \%$ of the March samples and $68 \%$ of the May samples.

\section{Mass change}

Absolute growth rate averaged $0.03 \mathrm{~kg} \mathrm{~d}^{-1}(0.01 \mathrm{~kg}$ $\mathrm{d}^{-1} \mathrm{SE}$ ) and percent daily mass gain averaged $0.06 \pm$ $0.02 \%$ (SE) for 37 seals for the time period between first capture (in December) and third capture (in May). The duration, or days between first and third capture, ranged from 142 to $188 \mathrm{~d}$. One seal (treated female yearling) gained mass at an exceedingly high rate. Her gain in mass was confirmed to be accurate via a subsequent capture and was not based on measurement error. We performed our analyses with and without this apparent outlier. However, overall patterns of significance did not change with her inclusion. We tested age class as 2 (young-of-the-year versus older juveniles) and 3 (young-of-the-year, $1 \mathrm{yr}$ old, 2 yr old) groups; however, patterns of significance in our subsequent analyses remained the same with either grouping.

A GLM for percent daily growth rate as a repeated measures variable showed that interval was significant, as well as treatment and age between the 2 treatment intervals (December to March versus March to May; Table 3). All seals gained more mass in the second interval (March to May). Treated and control seals had similar growth rates in the first interval (December to March); however, treated seals appeared to gain more mass than control seals in the second interval (March to May; Fig. 1). Youngof-the-year had the greatest difference in growth rate between intervals; they were the only age class to lose mass during any period of the study (first interval only) but significantly reversed this trend in the second interval. However, older juveniles grew more steadily and differed little between the 2 intervals.

Across both intervals (i.e. betweensubjects tests), only age was significant (Table 3). Older juveniles gained more mass on average than young-ofthe-year seals (Table 4). Sex and duration were not significant in our model (for either within- or betweensubject tests). 
We explored percent daily growth rate further with an ANOVA to test the effects of treatment, age, sex, and duration during the second interval (March to May) alone. Treatment and age again were signifi-

Table 3. Monachus schauinslandi. Repeated measures general linear model for percent daily growth rate $\left(\mathrm{kg} \mathrm{d}^{-1}\right)$ of 36 juvenile Hawaiian monk seals at Laysan Island. Interval consists of interval 1, the time between the December and March treatments, and Interval 2, the time between the March and May treatments

\begin{tabular}{|c|c|c|c|}
\hline Model & Source & $F$ & $\mathrm{p}(\alpha=0.05)$ \\
\hline \multirow{4}{*}{$\begin{array}{l}\text { Within-subjects } \\
\text { tests }\end{array}$} & All tests & 4.62 & 0.01 \\
\hline & Interval & 36.31 & $<0.0001$ \\
\hline & nterval $\times$ Treatment & 5.49 & 0.03 \\
\hline & Interval $\times$ Age & 8.22 & 0.01 \\
\hline \multirow{2}{*}{$\begin{array}{l}\text { Between-subjects } \\
\text { tests }\end{array}$} & All tests & 2.86 & 0.050 \\
\hline & Age & 7.76 & 0.01 \\
\hline
\end{tabular}

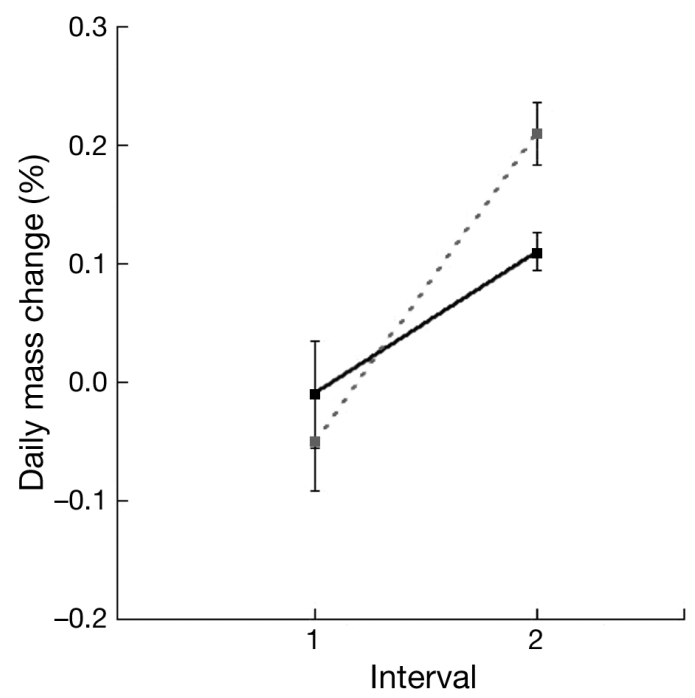

Fig. 1. Monachus schauinslandi. Percent $( \pm \mathrm{SE})$ growth rate of juvenile Hawaiian monk seals (all ages combined) according to their treatment status with antihelminthic treatment (control, solid line; treated, dotted line) over 2 time intervals. Interval 1 is the time between the December and March treatments; Interval 2 is the time between the March and May treatments

Table 4. Monachus schauinslandi. Mean total mass change and absolute and percent daily growth rate of juvenile Hawaiian monk seals from December 2009 to May 2010. Values in parentheses are SE

\begin{tabular}{|c|c|c|c|c|}
\hline \multirow{2}{*}{$\begin{array}{l}\text { Age } \\
\text { (yr) }\end{array}$} & \multirow{2}{*}{$\begin{array}{c}\text { Sample } \\
\text { size }\end{array}$} & \multirow{2}{*}{$\begin{array}{l}\text { Total mass } \\
\text { change }(\mathrm{kg})\end{array}$} & \multicolumn{2}{|c|}{ Growth rate } \\
\hline & & & $\operatorname{Mass}\left(\mathrm{kg} \mathrm{d}^{-1}\right)$ & $\% d^{-1}$ \\
\hline 1 & 23 & $0.04(10.5)$ & $0.002(0.013)$ & $0.04(0.03)$ \\
\hline 2 & 6 & $11.0(3.3)$ & $0.066(0.025)$ & $0.1(0.04)$ \\
\hline 3 & 8 & $13.5(2.7)$ & $0.086(0.022)$ & $0.1(0.02)$ \\
\hline
\end{tabular}

cant predictors of growth rate (ANOVA, $\mathrm{R}^{2}=0.14$, $\left.F_{32,4}=5.71, \mathrm{p}=0.02\right)$. Treated seals gained significantly more mass on a daily basis than control seals (Fig. 2). The mean \pm SE growth rate of older juveniles $\left(0.10 \pm 0.027 \mathrm{~kg} \mathrm{~d}^{-1}\right.$ for $2 \mathrm{yr}$ olds and $0.15 \pm 0.021 \mathrm{~kg}$ $\mathrm{d}^{-1}$ for 3 yr olds) was significantly greater than that of young-of-the-year $\left(0.067 \pm 0.012 \mathrm{~kg} \mathrm{~d}^{-1}\right)$. Sex and duration were not significant.

\section{Trends in mass change during the first year post weaning}

For 19 seals aged from weaning to 1 yr old, we followed their change in mass for 10 mo. After the May treatment of all 3 age classes, we continued to treat only the youngest seals (yearlings) in the following August and followed up with their final weighing in October. We performed a GLM on percent daily mass gain as a repeated measures variable for this subset of seals; however, interval (but not treatment) and sex or duration were significant. Percent daily mass gain appeared greater in treated versus control seals during the second interval only (i.e. March to May; Fig. 3). However, the sample size was low (19 seals), and molting was a potentially confounding factor to mass gain in the final months of the study. For example, 2 of the 10 control seals started their molt after

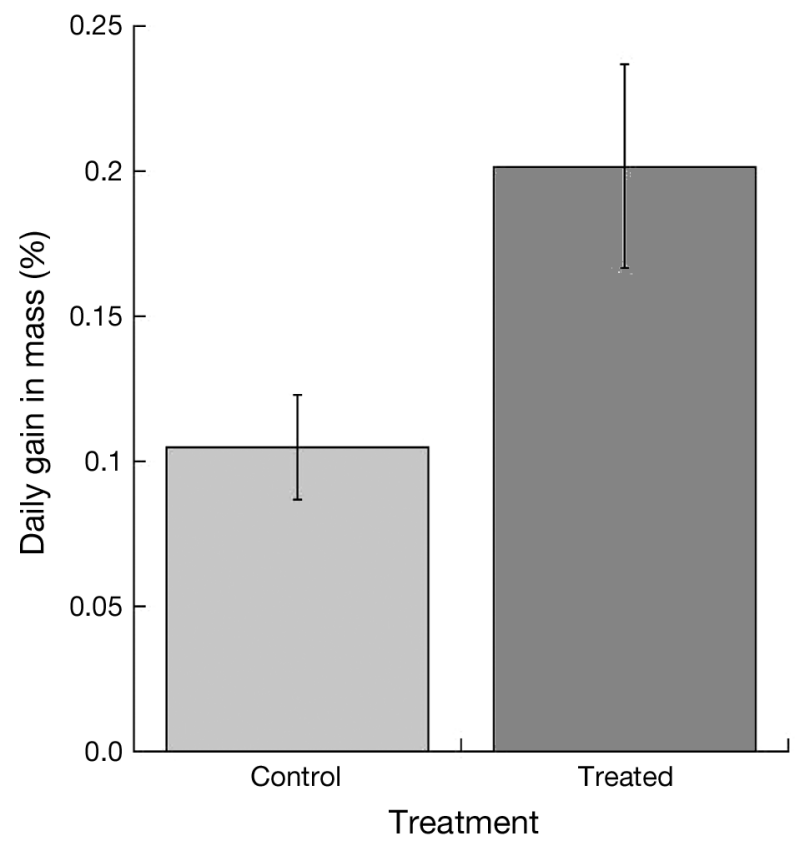

Fig. 2. Monachus schauinslandi. Significant difference between the percent gain $( \pm \mathrm{SE})$ in mass on a daily basis for treated versus control Hawaiian monk seals during March to May 2010 (all ages combined) 


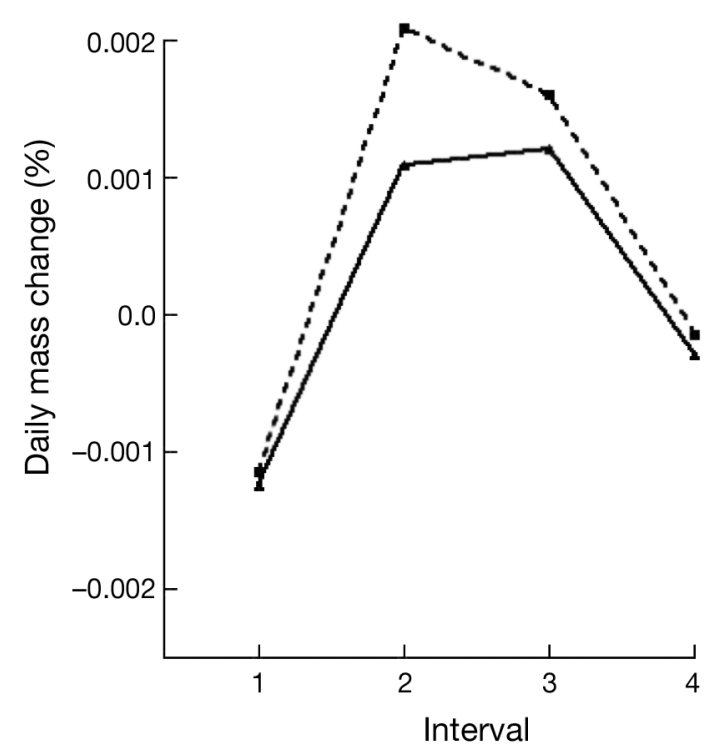

Fig. 3. Monachus schauinslandi. Percent gain in mass on a daily basis for control (solid line) and treated (dotted line) yearling Hawaiian monk seals across their first year post weaning. Intervals 1 to 4 represent the time between treatments and final measurements, i.e. between December and March, March and May, May and August, and August and October, respectively

the October weighing; therefore, the weight loss expected to accompany molting is not incorporated in their mass measurements, whereas it is for the remaining 18 seals.

\section{Reactions to capture and treatment}

Typically, seals entered the water within minutes of being released, with no indication of adverse effects of capture or treatment. However, we recorded adverse outcomes for 2 seals treated during the course of the study. One seal displayed signs of respiratory distress and another developed an abscess at the injection site (Table 5). Three other seals developed minor swellings near their injection sites within days of treatment; these swellings subsided on their own within 1 to 3 wk (Table 5). All 3 seals had a prior wound history unrelated to this study (e.g. shark wounds and flipper wounds). One seal that had a swelling was reinjected at the next treatment period and did not develop another swelling. As a precaution against further swellings, we standardized protocols for cleaning the injection site, improved restraining techniques (e.g. researchers positioned themselves in a manner which increased leverage and control of bucking or rolling animals), and split the praziquantel dose for half of the treated seals to test whether reducing the injected volume might mitigate swelling. The dose was divided between 2 bilateral intramuscular injections, each injection with a volume of $5 \mathrm{ml}$ or less for 5 treated seals in August. The maximum injection volume for the split-dose group was $3.7 \mathrm{ml}$ for an $85 \mathrm{~kg}$ seal, and $6.2 \mathrm{ml}$ for a $71 \mathrm{~kg}$ seal in the single-dose group. Subsequently, no injection site swellings occurred in any of the treated seals.

In addition, a captive juvenile Hawaiian monk seal (born in 2008 in the Hawaiian Islands, in captivity at Long Marine Laboratory, Santa Cruz, California) was treated with praziquantel (injection) of the same dosage $\left(5 \mathrm{mg} \mathrm{kg}^{-1}\right)$ in February 2010 and developed an injection site swelling within $10 \mathrm{~d}$ post treatment (D. Kasper pers. comm.). The swelling was lanced, cleaned, and subsequently healed; however, no signs of infection occurred (i.e. no elevated white blood cell count nor discharge consistent with infection). Cestode infection was apparent before and after treatment for this seal.

\section{DISCUSSION}

Although treatment of seals enhanced mass gain during the March to May interval, additional research is required to conclusively test our primary hypothesis that intermittently reducing parasite burden improves body condition in this species. Administering medication to animals in a wild setting on a

Table 5. Monachus schauinslandi. Summary of injection site swellings and abscesses in Year 1 of the deworming study for praziquantel at a dose of $5 \mathrm{mg} \mathrm{kg}^{-1}$

\begin{tabular}{|lccccl|}
\hline Seal ID & $\begin{array}{c}\text { Mass } \\
(\mathrm{kg})\end{array}$ & $\begin{array}{c}\text { Praziquantel } \\
(\mathrm{ml})\end{array}$ & Reaction & Treatment & Subsequent condition \\
\hline TW44 & 59 & 5.3 & Large abscess & Lanced, cleaned & Healed, gain in mass apparent \\
TW28 & 58 & 5.3 & Minor swelling & None & Resolved, gain of 20 kg \\
TA92 & 54.5 & 4.8 & Minor swelling & None & Resolved, gain of $8 \mathrm{~kg}$ \\
TA46 & 61.5 & 5.7 & Minor swelling & None & Resolved, loss of $3 \mathrm{~kg}$ \\
\hline
\end{tabular}


large scale involves balancing feasibility, repeatability, and drug effectiveness while minimizing handling time of individuals. Finding an effective medication for a given species may also involve testing different routes of application (e.g. oral, injectable, topical) and adjusting the dosage accordingly (i.e. the minimum effective dose may be route dependent). For example, given the particular circumstance, 1 route may be more effective but prove to be less logistically feasible when treating tens or hundreds of individuals. Efficacy tests are important to ensure that the drug, route, and dosage selected accomplish the clinical objectives, especially when commercially available drugs primarily designed for domestic animals are applied to wild species.

\section{Feasibility of administering antihelminthics to free-ranging seals}

We found that injectable antihelminthics were preferable to oral forms because of the relative ease of use and accuracy of dosing they provided; also, and the injections can be made with little risk of harm to seals. However, we were concerned with the association of injectables and formation of injection site swellings and abscesses. Although we were only able to apply the improved methods during the fourth interval of the Laysan study, we were encouraged to see that no injection site swellings occurred for the 11 treated seals.

One potential limitation of repeated capture and treatment is a possible behavioral response to capture. Field researchers reported that after multiple captures, individual seals became skittish and more evasive. This was an expected outcome, as most Hawaiian monk seal research is observational and seals are typically captured only briefly as weaned pups for tagging and sometimes for retagging if needed in later years. Repeated captures may thus become more difficult to achieve and might alter seal behavior or increase their level of stress or vigilance. These concerns must be weighed against benefits in endangered species such as this.

\section{Efficacy of injectable praziquantel}

Cestode infection was highly prevalent in the Laysan population of juvenile monk seals, as cestode eggs were present in nearly all collected scats. For seals across 6 breeding sites in the NWHI, 75\% of seals less than $2 \mathrm{yr}$ old and $95 \%$ of seals aged 2 to
4 yr were infected with Diphyllobothrium spp. The December and March nematode egg counts were similar to that of Contracaecum turgidum eggs detected by Reif et al. (2006) in monk seals across the NWHI. Injectable praziquantel did not appear to eliminate adult cestodes, as was evident from the fact that eggs were found in feces collected 10 to $22 \mathrm{~d}$ post treatment from a subset of seals.

Although infection was not eliminated, it is not known whether these seals' parasite loads were reduced because fecal egg counts are an unreliable indicator of cestode worm burden (Andrews \& Thomas 1983, Cheng 1986). It is possible that the particular strains or species infecting monk seals are not affected by the drug, or perhaps more likely, that the intramuscular route did not result in adequate levels of drug reaching the parasite. Captive studies with seals carrying parasite infections would help clarify these issues.

The survivorship of seals in our study was high; $100 \%$ of 2 and 3 yr olds and $85.7 \%$ of young-of-theyear in the study were sighted alive at the conclusion of the study. Thus, there was little potential for treatment to assist this set of seals in terms of survival. The 4 seals that disappeared were arguably all impacted by other factors that did not particularly implicate deworming treatment as a contributor factor in their mortalities.

Treated seals of all ages gained significantly more mass from March to May than control seals; however this was not the case in other periods and not for the overall study period. We are uncertain as to why benefits of treatment were suggested only during this season. However, this is likely not attributable to the ontogeny of new foraging skills because this gain in mass applied to 1, 2, and $3 \mathrm{yr}$ old juveniles. The species or strains of Diphyllobothrium that dominate may fluctuate on a seasonal basis. The species or strain that praziquantel is most effective at killing may dominate in the spring, whereas other species or strains that are more resistant to praziquantel may dominate at other times of the year, as observed in wild Soay sheep with nematode infection following antihelminthic treatment (Craig et al. 2009). Alternatively, there could be an interaction between nutritional status and innate resistance to parasites, with animals in poorer nutritional condition during March to May being more affected by parasite infections.

Overall, additional research is needed to determine the efficacy of the antihelminthic praziquantel in intermittently lessening cestode burden in juve- 
nile Hawaiian monk seals and improving their condition and survivorship. Our research here indicates that injectable praziquantel may provide some benefit to seals by improving their condition at select times. However, questionable efficacy suggests that a different route of administration or dosage of praziquantel or a different antihelminthic may be more helpful for this species.

Acknowledgements. We thank the veterinarians (H. Harris and E. Anderson) and the field staff (G. Johnson, S. Chinn, S. Conlon, C. Siudzinski, A. Kauffman, R. Marshall, E. Pickett, A. Wong, and A. Fox) for their hard work and care in helping execute this study. Also, a special thanks to B. Braun, B. Harting, T. Johanos, and C. Littnan for aiding in the design and development of this research. This study was conducted in accordance with institutional, national, and international guidelines concerning the use of animals in research (IACUC protocol number 03-007-7) and the sampling of endangered species (Endangered Species Act permit 10137-05).

\section{LITERATURE CITED}

Andrews P, Thomas H (1983) Praziquantel. Med Res Rev 3: $147-200$

Baker JD (2008) Variation in the relationship between offspring size and survival provides insight into causes of mortality in Hawaiian monk seals. Endang Species Res 5: $55-64$

Cheng TC (1986) General parasitology. Academic Press, Division of Hardcourt Brace \& Company, New York, NY

> Craig BH, Jones OR, Pilkington JG, Pemberton JM (2009) Re-establishment of nematode infra-community and host survivorship in wild Soay sheep following antihelminthic treatment. Vet Parasitol 161:47-52

Editorial responsibility: Clive McMahon,

Darwin, Australia
Dailey MD, Santangelo RV, Gilmartin WG (1988) A coprological survey of helminth parasites of the Hawaiian monk seal of the northwestern Hawaiian Islands. Mar Mamm Sci 4:125-131

$>$ DeLong R, Orr A, Jenkinson R, Lyons E (2009) Treatment of northern fur seal (Callorhinus ursinus) pups with ivermectin reduces hookworm-induced mortality. Mar Mamm Sci 25:944-948

Dierauf LA, Gulland FMD (eds) (2001) CRC handbook of marine mammal medicine. CRC Press, Boca Raton, FL

Faizal ACM, Rajapaksha WRAKJS, Rajapakse RPVJ (2002) Benefit of the control of gastrointestinal nematode infection in goats in the dry zone of Sri Lanka. J Vet Med Ser B 49:115-119

Forbes AB (1993) A review of regional and temporal use of avermectins in cattle and horses worldwide. Vet Parasitol 48:19-28

Grafen A, Hails R (2004) Modern statistics for the life sciences. Oxford University Press, Oxford

> Gulland FMD, Albon SD, Pemberton JM, Moorcroft P, Clutton-Brock TH (1993) Parasite-associated polymorphism in a cyclic ungulate population. Proc Biol Sci 254:7-13

> Hudson PJ, Newborn D, Dobson AP (1992) Regulation and stability of a free-living host-parasite system: Trichostrongylus tenuais in red grouse. I. Monitoring and parasite reduction experiments. J Anim Ecol 61:477-486

Johanos T, Becker BL, Ragen TJ (1994) Annual reproductive cycle of the female Hawaiian monk seal, Monachus schauinslandi. Mar Mamm Sci 10:13-30

> Lello J, Boag B, Hudson PJ (2005) The effect of single and concomitant pathogen infections on condition and fecundity of the wild rabbit (Oryctolagus cuniculus). Int J Parasitol 35:1509-1515

Reif JS, Kliks MM, Aguirre AA, Borjesson DL, Kashinsky L, Braun RC, Antonelis GA (2006) Gastrointestinal helminths in the Hawaiian monk seal (Monachus schauinslandi): associations with body size, hematology, and serum chemistry. Aquat Mamm 32:157-167

Submitted: May 4, 2011; Accepted: June 27, 2011

Proofs received from author(s): September 29, 2011 